\title{
A magyar jogrendszerről és a magyar vállalkozói jogról - egy angol nyelvü kötet fényében
}

Sándor István szerkesztésében idén jelent meg egy angol nyelvủ tanulmánykötet ${ }^{1}$ a hazai „vállalkozói jogról”. Az alábbiakban ennek ismertetésére kerül sor, elsőként - a kötet szerkezetének megfelelően - néhány tartalmi kérdést emelve ki, majd azt követően rövid értékelést adva a munka egészéröl.

\section{Tartalmi kérdések}

\subsection{A vállalkozói jog magyar jogrendszerben elfoglalt helyéröl}

A rendszerváltás óta kevés olyan idegen nyelvű mủ jelent meg, mely a magyar jogrendszert egészében mutatta volna be. Ezt a hiányt pótolja a tudományos igénynyel, több szerző közremüködésével közzétett „Business Law in Hungary” címü kötet. A könyv ugyan „A magyar vállalkozói jog” címmel és tematikával jelent meg, de a vállalkozói jogot körülvevő, szinte teljes rendszerbe foglalt közjogi és magánjogi, anyagi és eljárásjogi jogszabályokat, a jogrendszer minden idevonatkozó elemét és fontosabb jogintézményét taglalja. Jelentős könyv ez, hiszen nemcsak alapvető tájékoztatást és útbaigazítást nyújt a külföldi érdeklődőknek (akár potenciális befektetőnek) a magyar jogszabályok tartalmáról, rendszeréröl, hanem rámutat a jogérvényesítés, azaz a jogi oltalom útjaira is. A vállalkozóinál tágabb jogi környezetre utal a könyvnek az a része, amely a magyar jog európai jogcsaládokba való tartozását taglalja, s ennélfogva egyfelöl a római jog, másfelöl az osztrák jog hatását mutatja $\mathrm{ki}$, nem mellőzvén azt az eredeti vonást sem, amely a magyar államberendezés kezdetétől, Werbőczy munkáján át a kuriális precedensjoghoz, majd újabban, a 19. század második felétől, azaz a modern polgári korszaktól kezdődően, a kódexjoghoz vezetett.

Messzemenően helyeselhető a szerkesztőnek a szerzők hozzájárulásával együttesen megvalósított elképzelése, hogy a hatályos magyar vállalkozói jog külföldieknek szánt bemutatása egymagában nem célszerü: ehelyett komplexitásra kell törekedni, és a hatályos magyar jogrendszernek a vállalkozói joggal összefüggő minden szegmensét be kell mutatni. Ezért vállalkoztak tehát a vállalkozói jog bemutatására oly módon, hogy azt az egész jogrendszer kereteibe, kontextusába állították. A szerzők a vállalkozói joganyagot (a kereskedelmi jog státuszjogi és dinamikus részét)

* Dr. Szalma József egyetemi tanár, Károli Gáspár Református Egyetem Állam- és Jogtudományi Kar Polgári Jogi és Római Jogi Tanszék, szalma.jozsef@kre.hu.

1 Sándor, István (ed.): Business Law in Hungary. Patrocínium Kiadó, Budapest, 2016, 774. 
immáron az új Ptk. fényében taglalják. A jogszabályi környezet ismertetésén, elemzésén túlmenően a könyv (feltehetően azért, mert elsősorban az angolszász jogi kultúrának szánták) jelentős részben a magyar bírói gyakorlatot, azaz a Kúria vállalkozói jogra vonatkozó elvi határozatait is tartalmazza, s így ad széles körü „precedensjogi" áttekintést.

\subsection{Az Alaptörvény és a vállalkozói jog}

A kötet első része (amely a magyar jogrendszerre és a jogászi hivatásra, tevékenységre vonatkozik) Szabó Zsolt, Udvary Sándor, Réti László és Tóth Ádám szerzői hozzájárulása révén az új magyar Alaptörvény alapelveire, az alapvető jogokra és az állam szerveire, szervezeti felépítésére, tehát az Országgyülésre, a köztársasági elnökre, a Kormányra, az Alkotmánybíróságra, az országgyülési biztosra, az igazságszolgáltatási szervekre és a helyi önkormányzatokra vonatkozó rendelkezések rendszerező bemutatását adja. Külön fejezet foglalkozik a bírósági rendszerrel, az ügyvédséggel és a közjegyzőkkel, valamint a közjegyzői mint peren kívüli eljárással. A magyar jogban a jogügyletek közhiteles igazolása, a közjegyzők alaki hozzájárulása ugyan fakultatív eszköz, de jogbiztonságot nyújtván a külföldi beruházóknak, természetesen a magyar jogrendszerben is egy fontos támasz. Lényeges rendelkezése az Alaptörvénynek a vállalkozói szabadság alapjogok körébe való beemelése.

\subsection{A magyar magánjog történeti fejlődésmenete és a hatályos magyar magánjog}

A könyv második része a magyar magánjogról szól. Ebben a magyar magánjog történetének állomásait Hamza Gábor akadémikus mutatja be, figyelemmel a római jogi hatásokra, Werbőczy Tripartitumára, a késői középkori, 1514 utáni jogfejlődésre, egészen a 19. századig. Ezt követően a hazai római jogtudomány és a magánjog 19. és 20. századi fejlődésmenetét, továbbá a római jognak a magyar magánjog 19-20. századi kodifikációs tervezeteire gyakorolt hatását ismerteti.

A tételes magyar magánjog felé haladva a könyv először a magyar magánjog alapelveivel foglalkozik: a jóhiszemúség és tisztesség, az együttműködés, a joggal való visszaélés tilalma szabályaival (Boóc Ádám). A jogalanyok (természetes és jogi személyek) elvi kérdéseivel Görög Márta foglalkozik. A családi tulajdon, azaz a házassági vagyonjog, különösképpen a házassági vagyonjogi szerződés vállalkozói jogi jelentőségét Barzó Tímea ismerteti. A házassági vagyonjogi szerződés jogi jelentősége egyfelöl abban áll, hogy amennyiben létezik ilyen, akkor az egyik házastársnak tulajdonában levő korlátlan felelősségü társaság felelősségi körébe nem vonható be a másik házastárs szerzeménye úgy, mint közös szerzemény esetén, másfelöl megléte (tágabb értelemben) a családi vállalkozások jogát érinti, az e körbe eső jogviszonyok rendezésére lehet alkalmas. A tulajdonjognak mint alaptörvényi jognak bemutatását Téglási András végezte el. Ezután Vörös Imre akadémikus tanulmánya következik, amely a magyar nemzetközi magánjog (kollíziós jog) szabá- 
lyait ismerteti, beleértve a személyi jogra, a szellemi alkotásokra, a szerződési jogra és a deliktuális felelősségre vonatkozó közösségi jogi kollíziós szabályokat (Róma I., II.). A következő alfejezetek az alapítványi jogot (Csehi Zoltán) és a vállalkozói státuszjogot, a vállalkozási alakzatokat (Papp Tekla) mutatják be. Ezt a kérdést vizsgálja meg közelebbröl Sárközy Szabolcs is, a társaságok elnevezése, tevékenysége és lajstromoztatási eljárása tekintetében. A társasági státuszjogot követően a polgári jogi és kereskedelmi szerződési jog, azaz az egyes kötelmi szerződések közös szabályait Gellén Klára ismerteti a szerződés létrejöttére, érvényességére és hatálytalanságára vonatkozó szabályokkal, beleértve a semmisségi és megtámadhatósági szabályokat is (jogügyleti akarathiba, tévedés, megtévesztés, színlelés). A kötelmi szerződések teljesítésének biztosítékairól és a szerződési felelősségről Leszkoven László írt tanulmányt. A biztosítéki célú tulajdonátruházásról és fajairól, valamint a vételröl Sándor István, a vállalkozói szerződésröl Boóc Ádám, a tervezési szerződésről Barta Judit, a biztosítási szerződésről Kovács Kázmér és Kovács Szabolcs, a bizalmi vagyonkezelöi szerződésröl (trust) pedig Menyhei Ákos és Sándor István írtak tanulmányt. A szellemi alkotások jogáról Grad-Gyenge Anikó nyújt tájékoztató jellegủ áttekintést, a személyiségi jogok oltalmáról pedig Hegedűs Bulcsú. A magyar tőkepiac szabályozásáról Kecskés András, a munka- és szociális jogról Homicskó Árpád, a médiajogról Pázmándi Kinga, az energiajogról Szuchy Róbert, az atomenergia-jogról Lamm Vanda akadémikus értekezik. A vállalkozói büntetöjog szabályait Dobrocsi Szilvia, a vállalkozói adójogot Menyhei Ákos dolgozta fel. Az államháztartási jogról, azaz annak bevételi és kiadási oldaláról (költségvetési úton támogatott szervezetek, biztosítási alapok, beruházási alapok, nyugdíjalapok, Magyar Nemzeti Bank) Bor Zoltán értekezik. Varga István kiváló áttekintést nyújt a polgári peres eljárásról, beleértve az állami bíróságok előtti eljárást, a mediációt és a választottbírósági eljárást. Az előzetes döntéshozatali eljárás bírói gyakorlatáról szóló átfogó tanulmányt Osztovits András és Muzsalyi Róbert írták meg. Kecskés László akadémikus a magyar választottbíráskodás jogi szabályozásának fejlődésmenetéről és a hatályos szabályozásról rajzolt átfogó képet. Végül a magyar végrehajtási jog fejlődésmenetét és hatályos rendszerét Schadl György mutatja be tanulmányában. A könyv tartalmazza a kötetben hivatkozott magyar és külföldi jogirodalom jegyzékét, a hivatkozott magyar és uniós jogszabályok jegyzékét, tárgyszójegyzéket, végül a szerzők jegyzékét.

\section{Rövid értékelés}

Habár e könyv szerkesztőjének és szerzőinek elsődleges célja a hatályos magyar jogrendszer, és ezen belül a vállalkozói jog bemutatása, a kötet kellő mértékben tartalmazza az egyes jogintézmények fejlődésmenetére vonatkozó ismereteket, továbbá az uniós joggal (azaz irányelvi joggal) való harmonizáció útjainak ismertetését. Szerepelteti a hazai és uniós jog alkalmazásának eredményeit, a bírói gyakorlatnak sokszor a törvényhozásra is kiható állásfoglalásait. $E$ könyv nemcsak a külföldi, hanem a hazai gyakorlati jogászok, nemkülönben a jogtudomány számára is értékes irodalom, forrás lehet. Fontos részeit képezi a magyar bírósági rendszer- 
nek, a polgári peres és nemperes eljárásnak, a végrehajtási eljárásnak, a közjegyzői eljárásnak, a cégeljárásnak, továbbá a választottbírósági eljárásnak a bemutatása, nemkülönben a Kúria jogépítő és jogértelmező szerepének kidomborítása. Az elméleti és jogtörténeti tanulmányokban kifejezésre jutott a magyar magánjog európai jogcsaládhoz való tartozása, beleértve a sajátosságokat, amelyek a kuriális jogalkalmazásban nyilvánultak meg, ami a polgári korszakban (különösen a 19. század utolsó harmadában) jogforrásként is szolgált a törvénnyel nem szabályozott jogviszonyokra nézve. Kiemelték a szerzők azt is, hogy a hosszú jogfejlődést a polgári korszakot megelőző rendi jogban a szokásjog is befolyásolta. Ma más formában ugyan, de az írott (pl. principles) és íratlan (nemzetközi) kereskedelmi szokások és szokványok, meghatározott mértékben és területen, azaz a nemzetközi kereskedelmi szerződéseknél szubszidiáriusan szintén jogforrásként szolgálnak. A Magyar Gazdasági Kamara mellett müködő Választottbíróság - felek közötti jogvita esetére szóló illetékességi kikötés és anyagi jogválasztási klauzula alapján - fontos, független intézménye a magyar (nemzetközi) kereskedelmi jognak.

$E$ kötet - minden fentebb említett tartalmi elemével - értékes hozzájárulás nemcsak a magyar vállalkozói jognak, hanem a magyar jogrendszer egészének a megbízható ismertetéséhez. A hatályos joganyag idegen nyelven való hozzáférhetővé tétele útján, az áttekinthető, rendszerbe foglalt, pontos ismertetések révén hasznos útmutatóként szolgálhat a külföldi befektetőknek, és mellettük mindazok számára is, akik tájékozódni kívánnak a mai magyar jogról - azaz azoknak szól, akik a magyar jogot közelebbröl is meg kívánják ismerni, nem csupán azoknak, akik befektetői vagy más jogosultságaikat kívánják érvényesíteni Magyarországon. 